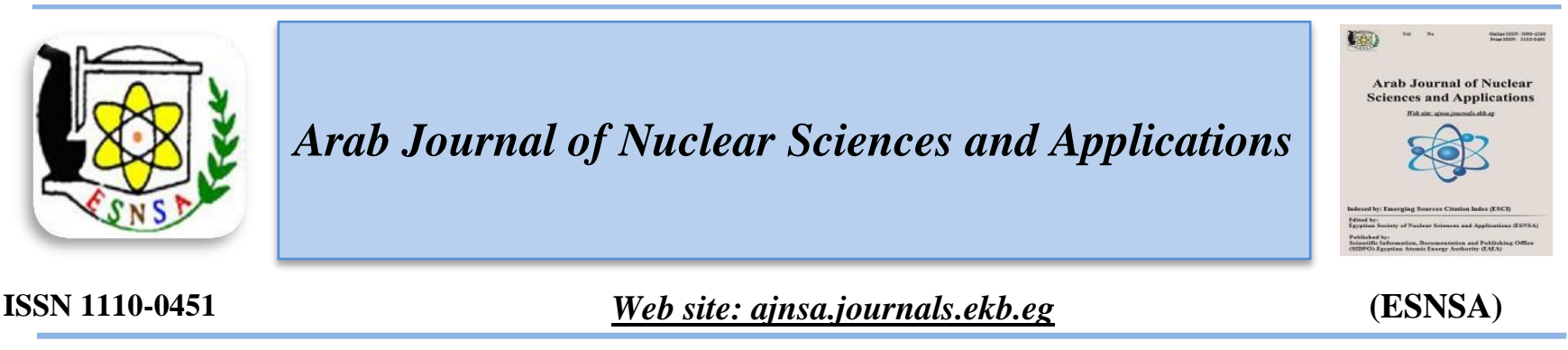

\title{
FTIR and UV Spectroscopic Analysis of Sparfloxacin Combined with Theoretical Study Based on DFT Calculations
}

\author{
Mamoun S. M. Abd El-Kareem ${ }^{1, *}$, Mohamed El-desawy ${ }^{1}$, A. M. $\operatorname{Rashad}^{2}$ \\ ${ }^{(1)}$ Molecular and atomic physics Unit., Experimental Nuclear Physics Department., Nuclear Research \\ Center, Egyptian Atomic Energy Authority, Cairo, Egypt \\ ${ }^{(2)}$ Accelerators and Ion Sources Department, Nuclear Research Center, Egyptian Atomic Energy Authority, \\ Cairo, Egypt.
}

Received 10 March 2020

Accepted 10 Dec. 2020
Sparfloxacin is analyzed using FTIR and UV-Vis spectrometers; theoretically the structure is geometry optimized using density functional theoretical approach with $B 3 L Y P$ method of calculation. After optimization, the vibrational frequencies are calculated. An acceptable match is observed between the measured and the calculated data. Electron density of the molecule is studied using natural bond orbital method. The energy difference was calculated and found to be $4.314 \mathrm{eV}$ and this represents the difference between the highest occupied molecular orbitals and lowest unoccupied molecular orbitals energies. This value explains the interaction between the charging transfer and the structure that affects the biological behavior. The electrostatic potential map of the molecule shows that the molecular sites having negative_potentials are those of oxygen, nitrogen and fluorine atoms and those having positive potentials are those of hydrogen atoms. The UV-VIS analyses of Sparfloxacin was carried out and the results confirmed the charge moving to the molecule.

Keywords: Quantum molecular physics; density functional theory; Infrared absorption; Orbital energies; Sparfloxacin antibiotic

\section{Introduction}

Sparfloxacin (IUPAC name: 5-amino-1cyclopropyl- 7-[(3R,5S)-3, 5-dimethylpiperazin-1yl]- 6,8-difluoro- 4-oxoquinoline- 3-carboxylic acid) is a fluoroquinolone antibiotic indicated for bacterial infections, it derived from nalidixic acid which is commonly used for treating the acute infections of the genitourinary scheme. The mechanism of action of Sparfloxacin is associated with inactivation of the bacterial DNA topoisomerase-II and weak interaction with the Bacterial DNA topoisomerase-IV, which leads to inhibition of the replication process of bacterial cells, leading to their death [1]. Sparfloxacin is one of antibacterial groups used to treat lung diseases, urinary tract infection and dermal allergies. Sparfloxacin is noted for its wide range of activities, strength and excellent pharmacokinetic profiles [2-4]. Sparfloxacin is one of the synthetic drugs which are confirmed and quantified by a multiresidue method which was improved by Lia et al. in 2009[5], they used a liquid chromatography-tandem mass spectrometer in their study. Shah et al. [6] have been developed a simple and accurate process for the spectrometric determination of bulk Sparfloxacin and for the

Corresponding author: Mamoun_sarhan@yahoo.com

DOI: 10.21608/ajnsa.2020.25609.1335

CScientific Information, Documentation and Publishing Office (SIDPO)-EAEA 
pharmaceutical preparations based on quantumchemical approaches compared to results of simple experimental (shake-flask) technique. KlosinskaSzmurlo et al. [7] identified the bioavailability in silico and in vitro methods of five selected fluoroquinolones. Investigation of the structure the metal complex of sparfloxacin has been conducted by El-Gamel and Zayed [8] Sparfloxacin has been investigated and analyzed after being irradiated in aqueous solution, using LC- UV detectionand LCMS/MS [9] Attia et al. reported three sensitive, selective and accurate Spectrophotometric and Spectrodensitometric methods for determination of sparafloxacin hydrochloride and besifloxacin hydrochloride in presence of bulk and pharmaceutical formulations of peroxide degradation products [10]. Concurrent short-time reversed phase HPLC method was developed and validated by Gul et al. [11] for the determination of Sparfloxacin, together with meloxicam, diclofenac sodium, flurbiprofen, ibuprofen, mefenemic acid and naproxen in a bulk material, pharmaceutical formulations and human serum. A new rapid and sensitive chemiluminescence method (CL) for determination of Sparfloxacin and other five fluoroquinolones namely, ciprofloxacin, gatifloxacin, levofloxacin, lomefloxacin $\mathrm{HCl}$, and ofloxacin is proposed by Abdel-aal et al. [12]. Jana et al. [13], used FT-IR and UV-Vis spectroscopic techniques to report the effect of the bio-field properties of sparfloxacin. Investigation of mass spectra for sparfloxacin structure obtained using electron ionization (EI) and chemical ionization (CI), procedures have been reported and discussed by Abd El-Kareem et al [14] who toke into consideration the fragmentation process under the two ionization procedures and used the semiempirical MNDO method. Literature shows that few studies tackle UV spectra and DFT calculations of sparfloxacin have been reported. All spectroscopies analyses by mean of FTIR and UV spectra together with quantum chemical calculations study will aid in Sparfloxacin structure investigation. So, the aim of the work is to study Sparfloxacin molecular structure using its experimental and theoretical vibrational spectra after geometrical optimization using density functional theory DFT with B3LYP method of calculation [15] and 6-311G(d,p) basis set. Hence DFT models are widely used to study the properties of molecular dynamics, including the equilibrium structure and vibrational frequencies [16].

\section{Materials and Methods}

Sparfloxacin sample in its pure chemical form was obtained from El-Obour Pharmaceutical Company, Cairo, Egypt. FTIR spectra of the studied Sparfloxacin samples were recorded by AttenuatedTotal-reflection Fourier Transform Infrared spectroscopy (A T R -F T I R) using a Shimadzu IRTracer-100 spectrometer. The Geometry of the IR beam includes incidence at angle of $30^{\circ}$ enrolls in the range of $4000-400 \mathrm{~cm}^{-1}$ [17].

Ultraviolet-visible spectrum was performed using a PerkinElmer spectrophotometer (type Lamda-25), registered in the wavelength range of $200-400 \mathrm{~nm}$ at ambient atmosphere with air as a reference.

\section{Computational details}

The geometric optimization of the studied structure was conducted using density functional theoretical approach of B3LYP as illustrated in a previous study [18]. This method has been used at neutral state using Gaussian 09, Revision C.01 [19]. The optimized molecular geometry with numbering system of sperfloxacin drug is shown in Fig (1).

The ionization potential (I) is determined using the following relation [20-21]:

$$
I=-E_{\text {номо }} \text {, and } A=-E_{L U M O}
$$

Where, A is the electron affinity according to Koopmans' Theory. Electronegativity $(\chi)$ of the material together with global chemical rigidity and electronic chemical potential are calculated as follows [22, 23]:

$$
\begin{aligned}
& \mu=(\partial E / \partial N) v(r)=-\chi \\
& \eta=1 / 2(\partial \mu / \alpha N)(\vec{r})=1 / 2\left(\partial^{2} E / \partial^{2} N\right) v(\vec{r})
\end{aligned}
$$


Where, $\mathrm{E}$ is the energy, $\mathrm{N}$ is the number of electrons in external potential of the molecular system under consideration.

From these equations,

$$
\chi=(I+A) / 2, \eta=(I-A) / 2 \text {, and } \mu=-\chi
$$

The electrophilicity index $(\omega)$ and the global chemical softness (S) are defined as follows [24, 28]:

$$
S=1 / 2 \eta, \text { and } \omega=\mu^{2} / 2 \eta
$$

\section{Results and Discussion}

Molecular geometry

Sparfloxacin optimization and getting a numbered system was carried out using DFT in B3LYP as shown in Fig.(1). The studied molecule has two C$\mathrm{F}$ bond lengths, eight $\mathrm{C}-\mathrm{N}$ bond lengths, three $\mathrm{C}-\mathrm{O}$ bond lengths, sixteen $\mathrm{C}-\mathrm{C}$ bond lengths, sixteen $\mathrm{C}$ $\mathrm{H}$ bond lengths and three $\mathrm{N}-\mathrm{H}$ bond lengths. Experimental and calculated values are given in Table (1). The calculations showed the $\mathrm{C}-\mathrm{C}$ bond lengths are $\approx 1.4(\AA)$ and $\mathrm{C}-\mathrm{N}, \mathrm{C}-\mathrm{O}$ bond lengths are $\approx 1.3(\AA)$ and $\mathrm{C}$-F bond lengths are $\approx 1.4(\AA)$ in whole Sparfloxacin molecule. It was observed that the geometrical parameters (bond lengths and angles) estimated by B3LYP level were found to be in excellent agreement with experimental values as shown as in Table (1).

\section{NBO Analysis}

Natural Bond Orbital (NBO) is a valuable tool for electron distribution on the molecule [29] The interaction between bonding and antibonding molecular orbitals can be quantitatively described in terms of NBO approach that is expressed by means of second-order interaction energy perturbation $\mathrm{E}(2)$. This energy is the estimate of the off-diagonal element of the NBO Fock matrix. The stabilization energy E (2) associated with $\mathrm{i}$ (donor) $\rightarrow \mathrm{j}$ (acceptor) delocalization is estimated from the second-order perturbation approach as given below [30]:

$$
E(2)=\Delta E_{i j}=q_{i} \frac{F^{2}(i, j)}{\varepsilon_{j}-\varepsilon_{i}}
$$

Where, $q_{i}$ is the donor orbital occupancy, $\mathrm{E}_{\mathrm{i}}$ and $E_{j}$ are diagonal elements (orbital energies) and $F_{(i, j)}$ is the off-diagonal Fock matrix element.

Table (2) presents the NBO study of the most important hyperconjugative inter actions of Sparfloxacin which were formed because of the overlapping between $\pi(\mathrm{c}-\mathrm{c})$ and $\pi^{*}(\mathrm{c}-\mathrm{c})$ orbitals and the stabilization of the system was attained because of the intra-molecular charge transfer. Such interactions can be detected when the electron density increases in the orbital antibonding system. Some parts of the ring are stabilized because of the high interaction of the $p$ electrons of $\mathrm{C}-\mathrm{C}$ to anti $\mathrm{C}-\mathrm{C}$ and $\mathrm{C}-\mathrm{O}$ bond as shown in Table (2). The donor orbitals $\pi \mathrm{C}$ $\mathrm{C} \rightarrow \pi^{*} \mathrm{C}-\mathrm{C}$ and $\pi \mathrm{C}-\mathrm{C} \rightarrow \pi^{*} \mathrm{C}-\mathrm{O}$ gave more energy than $\sigma \mathrm{C}-\mathrm{C} \rightarrow \sigma^{*} \mathrm{C}-\mathrm{C}$. Highly strong interaction has been observed between the lone pair LP N(27) and the $\sigma^{*} \mathrm{C}(5)-\mathrm{C}(7)$ with energy $(54.88 \mathrm{kcal} /$ mol). LP $\mathrm{O}(14)$ only participates in $\mathrm{LPO}(14) \rightarrow \sigma^{*} \mathrm{C}(3)-\mathrm{C}(4)$ interaction with an important value of energy, as shown Table (2). The calculated interaction energies of the BD*(2)C(4)$\mathrm{O}(14)) \rightarrow \mathrm{BD}^{*}(2) \mathrm{C}(2)-\mathrm{C}(3)$ and $\mathrm{BD}^{*}(2) \mathrm{C}(6)-$ $\mathrm{C}(10) \rightarrow \mathrm{BD}^{*}(2) \mathrm{C}(5)-\mathrm{C}(7)$ are 192.56 and $329.32 \mathrm{kcal} / \mathrm{mol}$, respectively which indicate a remarkable stabilization in the molecule 


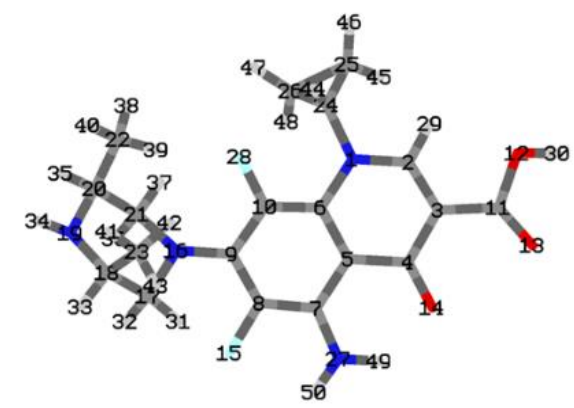

(a)

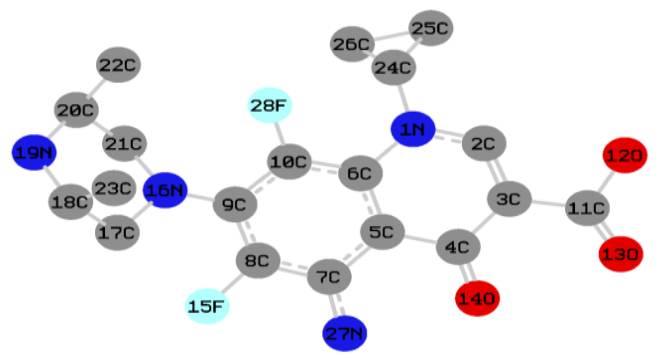

(b)

Figure (1: Part a) the optimized geometry of Sparfoxacin; Part b) The structure of Sparfoxacin with atoms numbered according to the text

Table (1): Optimized geometrical parameters for Sparfloxacin computed at B3LYP basis set

\begin{tabular}{|c|c|c|c|c|c|}
\hline Bond length & $\begin{array}{c}\text { values }(\AA ̊) \\
\text { B 3 LYP }\end{array}$ & Exp. values (Å) ${ }^{*}$ & Bond angle & $\begin{array}{c}\text { Value (o) } \\
\text { B3LYP }\end{array}$ & Exp. values $(\AA ̊ \cap){ }^{*}$ \\
\hline N1-C6 & 1.4172 & 1.349 & $\mathrm{~A}(\mathrm{C} 2, \mathrm{~N} 1, \mathrm{C} 24)$ & 118.7482 & 118.6 \\
\hline $\mathrm{N} 1-\mathrm{C} 24$ & 1.4666 & 1.452 & $\mathrm{~A}(\mathrm{C} 6, \mathrm{~N} 1, \mathrm{C} 24)$ & 122.3717 & 122.1 \\
\hline $\mathrm{C} 2-\mathrm{C} 3$ & 1.3701 & 1.354 & $\mathrm{~A}(\mathrm{~N} 1, \mathrm{C} 2, \mathrm{C} 3)$ & 120.96 & 120.9 \\
\hline $\mathrm{C} 3-\mathrm{C} 4$ & 1.4602 & 1.462 & $\mathrm{~A}(\mathrm{C} 2, \mathrm{C} 3, \mathrm{C} 4)$ & 121.9913 & 121.2 \\
\hline C3-C11 & 1.4653 & 1.440 & $\mathrm{~A}(\mathrm{C} 2, \mathrm{C} 3, \mathrm{C} 11)$ & 115.406 & 114.1 \\
\hline $\mathrm{C} 4-\mathrm{C} 5$ & 1.4677 & 1.430 & $\mathrm{~A}(\mathrm{C} 4, \mathrm{C} 3, \mathrm{C} 11)$ & 112.53 & 113.3 \\
\hline $\mathrm{C} 4-\mathrm{O} 14$ & 1.2672 & 1.250 & $\mathrm{~A}(\mathrm{C} 3, \mathrm{C} 4, \mathrm{C} 5)$ & 124.5542 & 125.1 \\
\hline C5-N6 & 1.4278 & 1.453 & $\mathrm{~A}(\mathrm{C} 3, \mathrm{C} 4, \mathrm{O} 14)$ & 119.345 & 119.3 \\
\hline $\mathrm{C} 5-\mathrm{C} 7$ & 1.4331 & 1.429 & $\mathrm{~A}(\mathrm{C} 5, \mathrm{C} 4, \mathrm{O} 14)$ & 118.493 & 117.8 \\
\hline C6-C10 & 1.3941 & 1.393 & $\mathrm{~A}(\mathrm{C} 4, \mathrm{C} 5, \mathrm{C} 6)$ & 121.885 & 122.8 \\
\hline $\mathrm{C} 7-\mathrm{C} 8$ & 1.4004 & 1.388 & $\mathrm{~A}(\mathrm{C} 4, \mathrm{C} 5, \mathrm{C} 7)$ & 122.519 & 122.9 \\
\hline C7-N27 & 1.36 & 1.348 & $\mathrm{~A}(\mathrm{C} 6, \mathrm{C} 5, \mathrm{C} 7)$ & 121.7274 & 121.0 \\
\hline $\mathrm{C} 8-\mathrm{C} 9$ & 1.396 & 1.385 & $\mathrm{~A}(\mathrm{C} 1, \mathrm{C} 6, \mathrm{C} 5)$ & 115.7499 & 116.1 \\
\hline C8-F15 & 1.4162 & 1.360 & $\mathrm{~A}(\mathrm{C} 1, \mathrm{C} 6, \mathrm{C} 10)$ & 120.0233 & 120.2 \\
\hline C9-C10 & 1.4125 & 1.389 & $\mathrm{~A}(\mathrm{C} 5, \mathrm{C} 6, \mathrm{C} 10)$ & 119.488 & 120.5 \\
\hline C9-N16 & 1.3935 & 1.391 & $\mathrm{~A}(\mathrm{C} 5, \mathrm{C} 7, \mathrm{C} 8)$ & 120.462 & 119.3 \\
\hline C10-F28 & 1.4143 & 1.356 & $\mathrm{~A}(\mathrm{C} 5, \mathrm{C} 7, \mathrm{~N} 27)$ & 117.950 & 118.8 \\
\hline $\mathrm{C} 11-\mathrm{O} 12$ & 1.4076 & 1.257 & $\mathrm{~A}(\mathrm{C} 8, \mathrm{C} 7, \mathrm{~N} 27)$ & 122.1544 & 122.1 \\
\hline $\mathrm{C} 11-\mathrm{O} 13$ & 1.2302 & 1.245 & $\mathrm{~A}(\mathrm{C} 7, \mathrm{C} 8, \mathrm{C} 9)$ & 120.032 & 119.0 \\
\hline $\mathrm{N} 16-\mathrm{C} 17$ & 1.477 & 1.456 & $\mathrm{~A}(\mathrm{C} 7, \mathrm{C} 8, \mathrm{~F} 15)$ & 119.8188 & 120.9 \\
\hline $\mathrm{N} 16-\mathrm{C} 21$ & 1.4807 & 1.452 & $\mathrm{~A}(\mathrm{C} 9, \mathrm{C} 8, \mathrm{~F} 15)$ & 116.1591 & 116.2 \\
\hline $\mathrm{C} 17-\mathrm{C} 18$ & 1.539 & 1.510 & $\mathrm{~A}(\mathrm{C} 8, \mathrm{C} 9, \mathrm{C} 10)$ & 123.8131 & 122.5 \\
\hline C18-N19 & 1.4743 & 1.509 & $\mathrm{~A}(\mathrm{C} 8, \mathrm{C} 9, \mathrm{~N} 16)$ & 121.217 & 119.9 \\
\hline $\mathrm{C} 18-\mathrm{C} 23$ & 1.5442 & 1.512 & $\mathrm{~A}(\mathrm{C} 10, \mathrm{C} 9, \mathrm{~N} 16)$ & 122.4967 & 123.0 \\
\hline N19-C20 & 1.4754 & 1.496 & $\mathrm{~A}(\mathrm{C} 6, \mathrm{C} 10, \mathrm{C} 9)$ & 114.5906 & 116.9 \\
\hline $\mathrm{C} 20-\mathrm{C} 21$ & 1.5382 & 1.515 & $\mathrm{~A}(\mathrm{~N} 19, \mathrm{C} 20, \mathrm{C} 21)$ & 119.958 & 118.9 \\
\hline $\mathrm{C} 20-\mathrm{C} 22$ & 1.5438 & 1.505 & $\mathrm{~A}(\mathrm{~N} 19, \mathrm{C} 20, \mathrm{C} 22)$ & 119.4489 & 116.4 \\
\hline $\mathrm{C} 24-\mathrm{C} 25$ & 1.5151 & 1.518 & $\mathrm{~A}(\mathrm{C} 21, \mathrm{C} 20, \mathrm{C} 22)$ & 125.3843 & 124.7 \\
\hline $\mathrm{C} 24-\mathrm{C} 26$ & 1.5088 & 1.497 & $\mathrm{~A}(\mathrm{~N} 16, \mathrm{C} 21, \mathrm{C} 20)$ & 124.1734 & 122.8 \\
\hline $\mathrm{C} 25-\mathrm{C} 26$ & 1.5158 & 1.481 & & & \\
\hline
\end{tabular}


(*)Experimental values are taken from Ref Acta Cryst. (2000). C56, e115 \pm e116

Table (2) : Natural Bond Orbital of Sparfloxacin neutral molecule

\begin{tabular}{|c|c|c|c|c|}
\hline Donor $^{\text {ia }}$ & Acceptor ${ }^{j a}$ & $\underset{b}{E}(2)(\mathrm{kcal} / \mathrm{mol})$ & $\Delta \mathrm{E}$ a.u. & $\begin{array}{l}F(i, j) \\
\text { a.u. }\end{array}$ \\
\hline $\mathrm{BD}(2) \mathrm{C} 2 \mathrm{C} 3$ & $\mathrm{BD} *(2) \mathrm{C} 4-014$ & 26.83 & 0.28 & 0.079 \\
\hline $\mathrm{BD}(2) \mathrm{C} 2 \mathrm{C} 3$ & $B D *(2) C 11-013$ & 27.42 & 0.27 & 0.078 \\
\hline $\mathrm{BD}(2) \mathrm{C} 5 \mathrm{C} 7$ & $B D *(2) C 4-014$ & 29.15 & 0.25 & 0.078 \\
\hline $\mathrm{BD}(2) \mathrm{C} 5 \mathrm{C} 7$ & $\mathrm{BD}^{*}(2) \mathrm{C} 6-\mathrm{C} 10$ & 29.17 & 0.25 & 0.077 \\
\hline $\mathrm{BD}(2) \mathrm{C} 5 \mathrm{C} 7$ & $B D^{*}(2) \mathrm{C} 8-\mathrm{C} 9$ & 16.54 & 0.25 & 0.058 \\
\hline $\mathrm{BD}(2) \mathrm{C} 6 \mathrm{C} 10$ & $B D *(2) C 5-C 7$ & 11.09 & 0.30 & 0.055 \\
\hline $\mathrm{BD}(2) \mathrm{C} 6 \mathrm{C} 10$ & $B D *(2) C 8-C 9$ & 21.71 & 0.29 & 0.075 \\
\hline $\mathrm{BD}(2) \mathrm{C} 8 \mathrm{C} 9$ & $B D *(2) C 5-C 7$ & 23.84 & 0.29 & 0.079 \\
\hline $\mathrm{BD}(2) \mathrm{C} 8 \mathrm{C} 9$ & $\mathrm{BD}^{*}(2) \mathrm{C} 6-\mathrm{C} 10$ & 13.69 & 0.28 & 0.058 \\
\hline LP(1)N1 & $B D *(2) C 2-C 3$ & 46.83 & 0.29 & 0.108 \\
\hline LP(1)N1 & $\mathrm{BD} *(2) \mathrm{C} 6-\mathrm{C} 10$ & 38.80 & 0.28 & 0.094 \\
\hline $\operatorname{LP}(2) 012$ & $\mathrm{BD} *(2) \mathrm{C} 11-013$ & 37.58 & 0.31 & 0.100 \\
\hline $\mathrm{LP}(1) \mathrm{O} 13$ & $\mathrm{RY}^{*}(1) \mathrm{C} 11$ & 15.05 & 1.54 & 0.136 \\
\hline $\mathrm{LP}(2) 013$ & $\mathrm{BD}^{*}(1) \mathrm{C} 3-\mathrm{C} 11$ & 16.66 & 0.68 & 0.098 \\
\hline LP(2) 013 & $\mathrm{BD}^{*}(1) \mathrm{C} 11-\mathrm{O} 12$ & 37.14 & 0.51 & 0.124 \\
\hline $\mathrm{LP}(1) 014$ & $\mathrm{RY}^{*}(1) \mathrm{C} 4$ & 11.04 & 1.52 & 0.116 \\
\hline $\mathrm{LP}(2) 014$ & $\mathrm{BD} *(1) \mathrm{C} 3 \mathrm{C} 4$ & 17.96 & 0.72 & 0.103 \\
\hline LP(2)O14 & $\mathrm{BD}^{*}(1) \mathrm{C} 4-\mathrm{C} 5$ & 13.11 & 0.71 & 0.087 \\
\hline $\mathrm{LP}(2) \mathrm{O} 14$ & $\mathrm{BD}^{*}(1) \mathrm{N} 27-\mathrm{H} 49$ & 9.03 & 0.71 & 0.073 \\
\hline LP(3) F15 & $\mathrm{BD}^{*}(2) \mathrm{C} 8-\mathrm{C} 9$ & 12.27 & 0.40 & 0.071 \\
\hline $\mathrm{LP}(1) \mathrm{N} 16$ & $\mathrm{BD}^{*}(2) \mathrm{C} 8-\mathrm{C} 9$ & 28.29 & 0.25 & 0.079 \\
\hline LP (1)N19 & $\mathrm{BD} *(1) \mathrm{C} 18-\mathrm{C} 23$ & 9.63 & 0.60 & 0.069 \\
\hline LP (1) N19 & $B D^{*}(1) \mathrm{C} 20-\mathrm{C} 22$ & 9.31 & 0.60 & 0.068 \\
\hline LP (1)N27 & $B D *(2) C 5-C 7$ & 54.88 & 0.25 & 0.110 \\
\hline $\operatorname{LP}(3) \mathrm{F} 28$ & $\mathrm{BD} *(2) \mathrm{C} 6-\mathrm{C} 10$ & 12.36 & 0.40 & 0.071 \\
\hline$B D^{*}(2) C 4014$ & $\mathrm{BD} *(2) \mathrm{C} 2-\mathrm{C} 3$ & 192.56 & 0.01 & 0.074 \\
\hline$B D *(2) C 6$ C10 & $B D *(2) C 5-C 7$ & 329.32 & 0.01 & 0.077 \\
\hline$B D *(2) C 11013$ & $B D *(2) C 2-C 3$ & 101.29 & 0.02 & 0.070 \\
\hline
\end{tabular}

${ }^{\mathrm{a}}$ see Sparfloxacin numbering system and LP is lone pair.

${ }^{b} \mathrm{E}(2)$ second energy order

It could be noted that the carbon atom has positive and negative charge and hydrogen atomic charges is found to be totally positive and arranged in an the order from 0.19087 to 0.47904 due to charge transfer from $\mathrm{H}$ to carbon atom. Additionally, the three oxygen atoms are negative and arranged in an the order -0.54461 to -0.73027 , the magnitudes of the atomic charge of the three Nitrogen atoms have negative values and arranged in the order 0.38511 to -0.74591 and the magnitudes of the atomic charge of the two fluorine atoms are negative $(-0.37197,-0.37629)$ indicating that a
Sparfloxacin molecule has a highly electronegative atoms $\mathrm{O}, \mathrm{N}$ and $\mathrm{F}$ atoms as presented in Table (3). The authors of the present study suggest that N1 and $\mathrm{O} 14$ in Sparfloxacin qinolone ring have a lone pair electrons ionization processes which may take place at these atoms. The histogram of NBO atomic charges for Sparfloxacin at DFT/B3L Y P/6-311G level is shown in Figure (2).

The Highest_Occupied_Molecular_Orbital (HOMO) and the Lowest Unoccupied_Molecular Orbital (LUMO) are very important parameters for studying molecule kinetic stability $\mathrm{OMO}$ is

Arab J. Nucl. Sci. \& Applic. Vol. 54, No.1 (2021) 
responsible for donating an electron and LUMO is responsible for accepting this electron. The HOMO-LUMO energy values were calculated by B3 LY P method using 6-311 G (d, p) basis sets for evaluating the behavior of the compound under study. Figure (2) shows HOMO and LUMO of Sparfloxacin red color represent ing the positive area and green color representing negative HOMO which is basically consisted of $\mathrm{O}(12) \mathrm{O}(14), \mathrm{O}(18)$ and $\mathrm{N}(1)$ of bicyclic ring, $\mathrm{N}(16)$ of piperazyinyl ring. $\mathrm{N}(27)$ attached to the two methyl groups. LUMO is distributed inside molecule except the methyl groups bounded to $\mathrm{N}(27)$. The energy gap $\Delta \mathrm{E}$ is equal to the absolute value of the (HOMO LUMO) energy difference, hence it is an important value which serves as an index of stability. A large HOMO-LUMO gap, involves the lower reactivity of high molecular stability in chemical reactions $[31,32]$. Figure (3) shows the energy distribution for the molecular orbits HOMOLUMO with the related energy gap. The energy gap value of HOMO-LUMO $\triangle \mathrm{E}$ was found to be $4.086 \mathrm{eV}$, which explains biological activity properties. The relative high values of $\triangle \mathrm{E}, \mathrm{HOMO}$, LUMO show high chemical stability and low reactivity of the structure. Other energies and physical properties have been calculated and reported in Table (4) which helps to understand the molecular structure and reactivity.

Table (3): NBO and Mulliken atomic charges of Sparfloxacin drug calculated at DFT/B3 LYP/6-311G level of theory

\begin{tabular}{|c|c|c|c|c|c|c|c|c|}
\hline Atom & $\mathrm{NBO}^{\mathrm{ac}}$ & Mulliken ${ }^{\text {ac }}$ & Atom & $\mathrm{NBO}^{\mathrm{ac}}$ & Mulliken ${ }^{\text {ac }}$ & Atom & $\mathrm{NBO}^{\mathrm{ac}}$ & Mullikenac \\
\hline $\mathrm{N} 1$ & -0.38511 & -0.782212 & $\mathrm{H} 40$ & 0.19087 & 0.157470 & $\mathrm{H} 46$ & 0.21264 & 0.200562 \\
\hline $\mathrm{C} 2$ & 0.12926 & 0.227414 & $\mathrm{H} 41$ & 0.19484 & 0.163328 & $\mathrm{H} 47$ & 0.21209 & 0.198361 \\
\hline $\mathrm{C} 3$ & -0.26880 & -0.262686 & $\mathrm{H} 42$ & 0.20036 & 0.189747 & $\mathrm{H} 48$ & 0.21360 & 0.202252 \\
\hline $\mathrm{C} 4$ & 0.46048 & 0.444639 & $\mathrm{O} 12$ & -0.73027 & -0.615042 & H49 & 0.43307 & 0.382845 \\
\hline $\mathrm{C} 5$ & -0.16888 & -0.225364 & $\mathrm{O} 13$ & -0.54461 & -0.328071 & $\mathrm{H} 50$ & 0.39067 & 0.342179 \\
\hline C6 & 0.14302 & 0.477575 & O14 & -0.61545 & -0.431057 & $\mathrm{H} 43$ & 0.19531 & 0.166800 \\
\hline $\mathrm{C} 7$ & 0.17704 & 0.422334 & F15 & -0.37629 & -0.347725 & $\mathrm{C} 23$ & -0.59877 & -0.496579 \\
\hline $\mathrm{C} 8$ & 0.31550 & 0.170910 & N16 & -0.47895 & -0.649429 & $\mathrm{C} 24$ & -0.02587 & -0.000126 \\
\hline $\mathrm{C} 9$ & 0.10980 & 0.324875 & $\mathrm{C} 17$ & -0.18257 & -0.136223 & $\mathrm{C} 25$ & -0.39523 & -0.387134 \\
\hline $\mathrm{C} 10$ & 0.31335 & 0.220402 & $\mathrm{C} 18$ & -0.00173 & -0.052605 & $\mathrm{C} 26$ & -0.37978 & -0.330371 \\
\hline $\mathrm{C} 11$ & 0.75746 & 0.468526 & N19 & -0.69848 & -0.573318 & $\mathrm{~N} 27$ & -0.74591 & -0.911112 \\
\hline H34 & 0.35490 & 0.283192 & $\mathrm{C} 20$ & -0.00168 & -0.046082 & F28 & -0.37197 & -0.341801 \\
\hline H35 & 0.19259 & 0.175982 & $\mathrm{C} 21$ & -0.18074 & -0.178286 & $\mathrm{H} 29$ & 0.24168 & 0.246166 \\
\hline H36 & 0.18450 & 0.186254 & $\mathrm{C} 22$ & -0.59544 & -0.484849 & $\mathrm{H} 30$ & 0.47904 & 0.386661 \\
\hline H37 & 0.21149 & 0.198478 & $\mathrm{H} 43$ & 0.19531 & 0.166800 & $\mathrm{H} 31$ & 0.21154 & 0.192832 \\
\hline $\mathrm{H} 38$ & 0.19416 & 0.161405 & N44 & 0.22054 & 0.219535 & H32 & 0.19112 & 0.187865 \\
\hline H39 & 0.20526 & 0.193741 & $\mathrm{H} 45$ & 0.21548 & 0.207893 & $\mathrm{H} 33$ & 0.19486 & 0.179847 \\
\hline
\end{tabular}




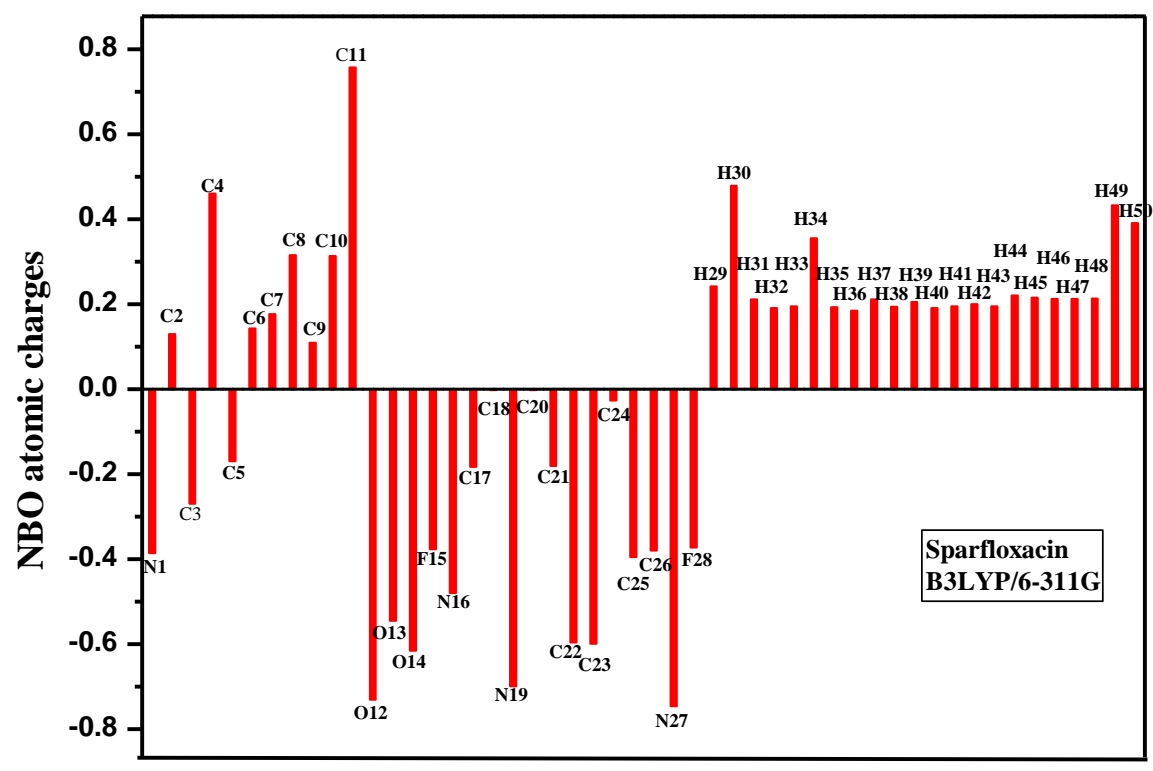

Figure (2): NBO atomic charges Sparfloxacin drug calculated at DFT/B3 L Y P/6-311G level of theory

Table (4): Energies and some physical properties of Sparfloxacin calculated at B3LYP/6-311G(d,p) level

\begin{tabular}{cc}
\hline Molecular parameters & B3 L Y P/6-311G(d,p) \\
Total energy (HT) & -1381.5592 \\
Dipole moment (Deby) & 7.1431 \\
$\mathrm{E}_{\text {Homo }}(\mathrm{eV})$ & -5.721 \\
$\mathrm{E}_{\text {Lumo }}(\mathrm{eV})$ & -1.635 \\
$\Delta \mathrm{E}_{\text {gap }}(\mathrm{eV})$ & -4.086 \\
Ionization potential_IP $(\mathrm{eV})$ & 5.721 \\
Electron affinity_EA $(\mathrm{eV})$ & 1.635 \\
Hardness $(\eta)(\mathrm{eV})$ & 2.043 \\
Softness $(\mathrm{S})(\mathrm{eV})-1$ & 0.4895 \\
Electronegativity $(\chi)$ & 3.678 \\
Chemical potential, $(\mu)$ & -3.678 \\
\hline
\end{tabular}




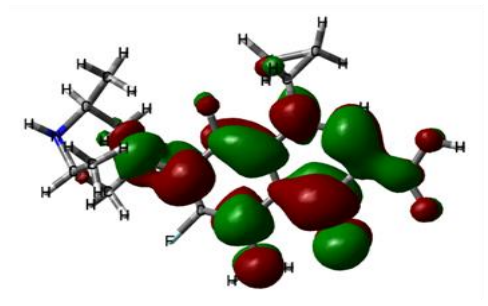

LUMO (-1.635)

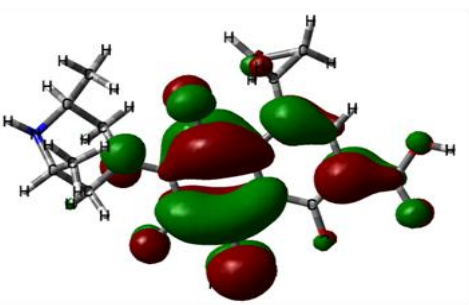

$\Delta \mathrm{E}_{\text {номо-цимо }}=-4.086$

Figure (3): HOMO and LUMO, energy gap of Sparfloxacin

\section{Molecular Electrostatic Potential (MEP)}

MEP together with electron density are very important to indicate the sites for electrophilic and nucleophilic reactions [34] and to identify reactive sites of electrophilic or nucleophilic properties of Sparfloxacin. Red color surface means negative and accept proton while blue is positive and do not accept proton Figure (4) shows the total electron density surface mapped with molecular electrostatic potential MEP plot in solid and mesh view. From the MEP, it is blurred that the negative area covers the $\mathrm{C} 4=\mathrm{O} 14$ group of qinolone ring and
C11=013 group carboxyl group attached to the qinolone ring of the title compound, another negative region were localized at $\mathrm{O} 12$ group carboxyl group, N27 at qinolone ring and N16, N19 of piperazinyl group attached with quinolone ring and the positive region is over the hydrogen of the aromatic qinolone ring and over the hydrogen of piperazinyl ring. The electrostatic potential value is largely responsible for bindings between the substrate and its receptor sites since the receptor and the corresponding ligands recognized 
recognize each other at their molecular surface [35].

\section{Vibrational assignments}

The Sparfloxacin molecule consists of 50 atoms and has144 symmetrical normal modes. Experimental and calculated FTIR and normal mode descriptions are presented in Table (5) ( Table S1 supplementary file) and are shown in Fig.(5).

Experimental FT-IR spectrum of Sparfloxacin is shown in Figure (5), which shows the vibrational peaks at $3093.64-3461.80 \mathrm{~cm}^{-1}$ related to $\mathrm{O}-\mathrm{H}$ and $\mathrm{N}-\mathrm{H}$ stretching. The vibrational peaks appeared at 2845.29-2962.12 $\mathrm{cm}^{-1}$ for C-H (CH3) stretching. Furthermore, the vibrational peaks were observed at $1716.12 \mathrm{~cm}^{-1}$ and $1640.78 \mathrm{~cm}^{-1}$ due to $\mathrm{C}=\mathrm{O}$ (COO-) and $\mathrm{C}=\mathrm{O}$ (pyridone) stretching, respectively. The IR peaks appeared at 1585.33 , and $1532.51 \mathrm{~cm}^{-1}$ related to $\mathrm{C}=\mathrm{C}$ (benzene ring) stretching and $\mathrm{N}-\mathrm{H}$ bending, respectively. $\mathrm{C}-\mathrm{H}$ bending and $\mathrm{C}=\mathrm{O}$ (COO-) stretching peaks appeared at 1439.40 and $1333.73 \mathrm{~cm}^{-1}$ respectively C-N (aryl) stretching and C-F stretching peaks were observed at $1183.98-1293.13 \mathrm{~cm}^{-1}$ and 1149 $.91 \mathrm{~cm}^{-1}$, respectively. Moreover, the IR peaks appeared at 1084.76, 1027.95, and $670.92 \mathrm{~cm}^{-1}$ were assigned to $\mathrm{C}-\mathrm{O}$ (COO-) stretching $\mathrm{C}-\mathrm{N}$ (alkyl) stretching, and $=\mathrm{C}-\mathrm{H}$ bending respectively. The FT-IR experimental data of Sparfloxacin was in well agreement with the calculated DFT and supported by the literature data [13].

\section{$U V$-vis studies and electronic properties}

UV data of Sparfloxacin have been carried out using TD-DFT calculations on Sparfloxacin at two states (gas phase and ethanol) and reported in Table (6). The theoretical and experimental UVvisible spectra are visualized in Figure $(6 \mathrm{a} \& \mathrm{~b})$. As can be seen from Table (6), the calculated absorption maxima values for the title compound were found to be $368.46,353.01$ and $330.74 \mathrm{~nm}$. This band is recorded experimentally as a shoulderat $294 \mathrm{~nm}$. The wavelength calculated at $368.46 \mathrm{~nm}$ ( $\mathrm{f}=0.0432$ ) primarily produced molecular orbital HOMO excitations to LUMO.
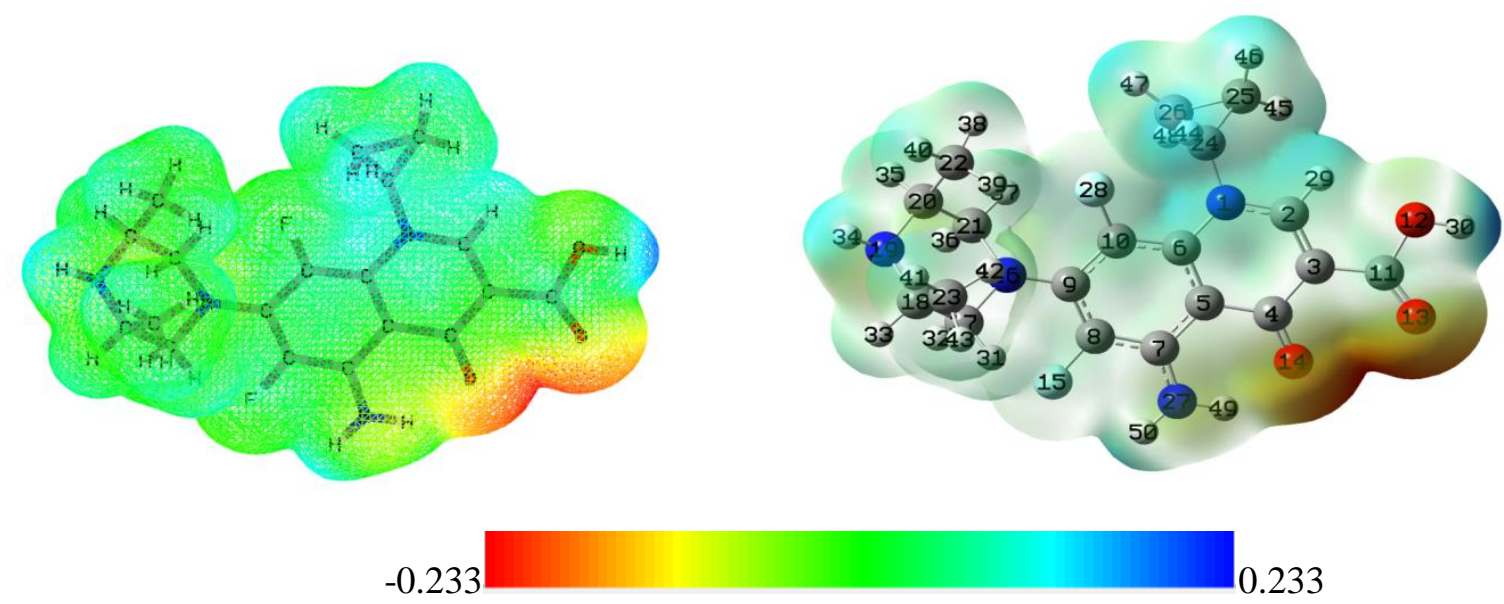

Figure (4): MEP mapped plot in (solid and mesh view) for Sparfloxacin calculated by B3 L Y P method 

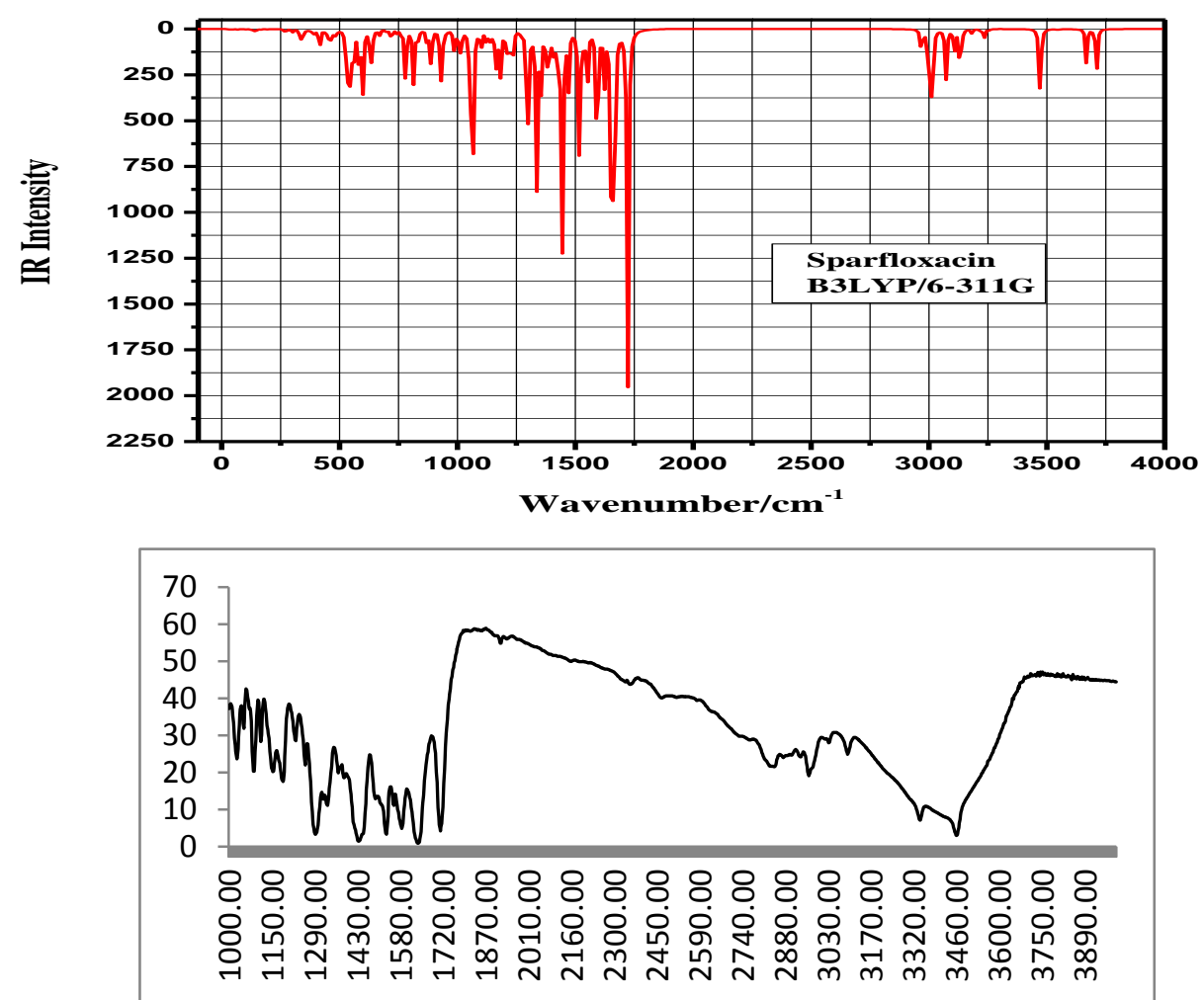

Figure (5): Calculated and experimental FTIR spectra of Sparfloxacin compound

Table (5): Experimental and calculated FTIR spectra of Sparfloxacin

\begin{tabular}{c|c|ccc}
\hline & $\begin{array}{c}\text { Observed } \\
\text { fundamentals }\left(\mathrm{cm}^{-1}\right)\end{array}$ & \multicolumn{3}{c}{$\begin{array}{c}\text { Calculated frequencies } v i\left(\mathrm{~cm}^{-1}\right) \\
\text { B3L Y } / 6-311 \mathrm{G}(\mathrm{d}, \mathrm{p})\end{array}$} \\
\hline number & & $\begin{array}{c}\text { Scal. } \\
\text { Frequency }\end{array}$ & $\begin{array}{c}\text { UnScal. } \\
\text { Frequency }\end{array}$ & IR Intensity \\
\hline 1 & 401 & 400.81388 & 414.9212 & 38.1746 \\
2 & 424 & 424.25986 & 439.1924 & 2.8214 \\
3 & 436 & 435.85476 & 451.1954 & 18.2919 \\
4 & 449 & 448.92512 & 464.7258 & 17.0394 \\
5 & 459 & 459.35609 & 475.5239 & 4.7524 \\
6 & 467 & 467.68861 & 484.1497 & 11.0851 \\
7 & 507 & 507.33866 & 525.1953 & 30.3541 \\
8 & 519 & 519.70365 & 537.9955 & 109.2297 \\
9 & 528 & 528.40519 & 547.0033 & 78.9699 \\
10 & 540 & 540.02308 & 559.0301 & 61.9497 \\
11 & 563 & 563.33865 & 583.1663 & 75.7629 \\
12 & 577 & 577.39047 & 597.7127 & 95.3488
\end{tabular}




\begin{tabular}{|c|c|c|c|c|}
\hline 13 & 579 & 578.82498 & 599.1977 & 0.9245 \\
\hline 14 & 609 & 608.51566 & 629.9334 & 45.2100 \\
\hline 15 & & 612.15111 & 633.6968 & 19.2710 \\
\hline 16 & 617 & 616.59703 & 638.2992 & 21.2538 \\
\hline 17 & & 645.38296 & 668.0983 & 10.5173 \\
\hline 18 & & 676.27409 & 700.0767 & 4.4375 \\
\hline 19 & 694 & 694.426 & 718.8675 & 19.2448 \\
\hline 20 & & 718.40937 & 743.6950 & 6.3458 \\
\hline 21 & 737 & 737.04573 & 762.9873 & 9.1156 \\
\hline 22 & & 752.74371 & 779.2378 & 82.1705 \\
\hline 23 & & 760.81513 & 787.5933 & 6.3225 \\
\hline 24 & & 783.84708 & 811.4359 & 15.0677 \\
\hline 25 & & 786.41123 & 814.0903 & 74.5999 \\
\hline 26 & 795 & 794.89764 & 822.8754 & 2.9149 \\
\hline 27 & & 803.06806 & 831.3334 & 13.0933 \\
\hline 28 & & 808.81122 & 837.2787 & 3.7330 \\
\hline 29 & 841 & 841.38339 & 870.9973 & 28.2241 \\
\hline 30 & 858 & 858.06998 & 888.2712 & 68.5820 \\
\hline 31 & & 892.31159 & 923.7180 & 15.5702 \\
\hline 32 & 901 & 900.69077 & 932.3921 & 85.6219 \\
\hline 33 & & 908.91809 & 940.9090 & 4.8283 \\
\hline 34 & & 954.21045 & 987.7955 & 14.5372 \\
\hline 35 & 960 & 959.55137 & 993.3244 & 1.0261 \\
\hline 36 & & 966.93277 & 1000.9656 & 13.6853 \\
\hline 37 & 980 & 980.06651 & 1014.5616 & 46.4282 \\
\hline 38 & 1010.00 & 1014.56565 & 1050.2750 & 27.2882 \\
\hline 39 & 1030.00 & 1026.27521 & 1062.3967 & 352.0324 \\
\hline 40 & 1060.00 & 1061.84729 & 1099.2208 & 29.6988 \\
\hline 41 & & 1063.08667 & 1100.5038 & 4.4099 \\
\hline 42 & 1080.00 & 1081.92618 & 1120.0064 & 4.6446 \\
\hline 43 & & 1083.80003 & 1121.9462 & 13.3013 \\
\hline 44 & 1090.00 & 1092.48205 & 1130.9338 & 6.2400 \\
\hline 45 & 1100.00 & 1102.49087 & 1141.2949 & 24.5487 \\
\hline 46 & & 1120.12279 & 1159.5474 & 21.3721 \\
\hline 47 & 1120.00 & 1124.21013 & 1163.7786 & 0.9440 \\
\hline 48 & 1130.00 & 1127.36122 & 1167.0406 & 61.9158 \\
\hline
\end{tabular}

Correction factor for B3 LY P/6-311G is 0.966 [https://cccbdb.nist.gov/vibscalejust.asp] 
Table (6): theoritical maximum absorption wavelengths $\left(\lambda_{\max }\right)$, excitation energies $(\Delta E)$ and oscillator strengths $(f)$ of Sparfloxacin by TD-DFT/B3LY P/6-311g method

\begin{tabular}{llll}
\hline Sparfloxacin & & Gas phase & In ethanol \\
\hline \multirow{3}{*}{ Excited State 1} & $\lambda \mathrm{Max}(\mathrm{nm})$ & 358.54 & 368.46 \\
\cline { 2 - 4 } & $\Delta \mathrm{E}(\mathrm{eV})$ & 3.4580 & 3.3650 \\
\cline { 2 - 4 } & $\mathrm{f}($ a.u. $)$ & 0.0302 & 0.0432 \\
\hline \multirow{2}{*}{ Excited State 2} & $\lambda \mathrm{Max}(\mathrm{nm})$ & 341.23 & 353.01 \\
\cline { 2 - 4 } & $\Delta \mathrm{E}(\mathrm{eV})$ & 3.6335 & 3.5122 \\
\cline { 2 - 4 } & $\mathrm{f}($ a.u. $)$ & 0.0466 & 0.1079 \\
\cline { 2 - 4 } & $\lambda \mathrm{Max}(\mathrm{nm})$ & 321.42 & 330.74 \\
\cline { 2 - 4 } Excited State 3 & $\Delta \mathrm{E}(\mathrm{eV})$ & 3.8573 & 3.7487 \\
\cline { 2 - 4 } & $\mathrm{f}($ a.u. $)$ & 0.0506 & 0.2148 \\
\hline
\end{tabular}
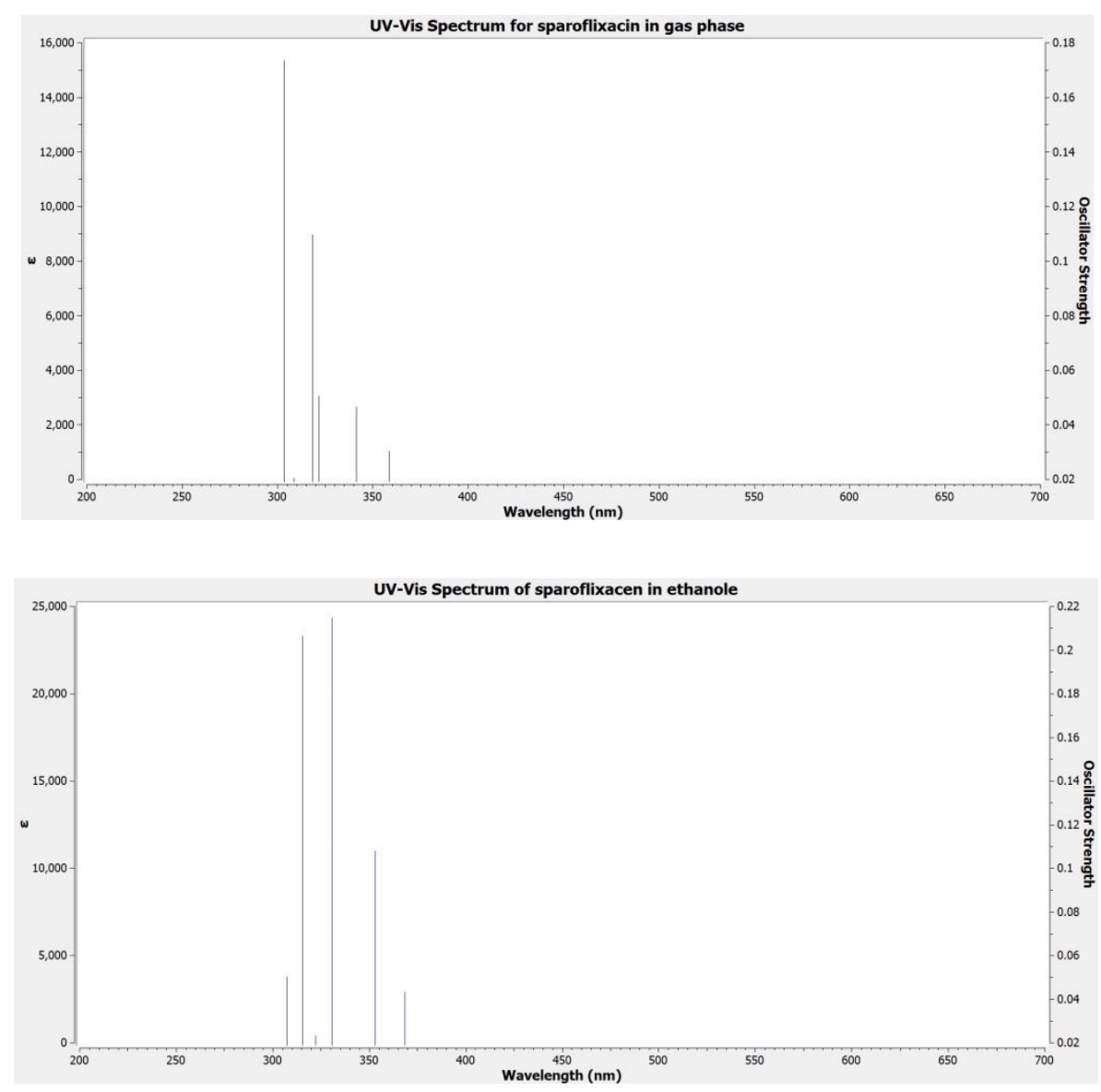

Figure(6a):Theoretical UV spectra in gas phase and ethanol 


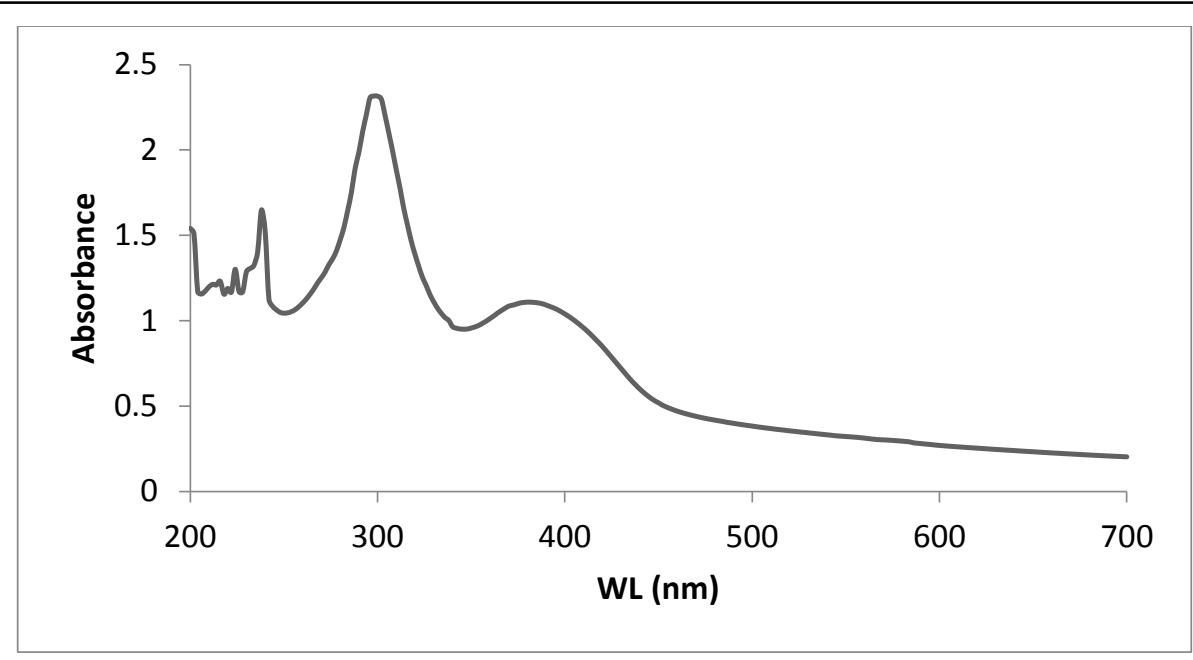

Figure (6 b): Experimental UV spectra

\section{Conclusions}

A complete vibrational dynamical and molecular structure analysis of Sparfloxacin has been performed, based on the quantum chemical approach by DFT (B3LYP) calculations. The spectral characterization studies such as FTIR for Sparfloxacin have been carried out. A good agreement was found between the experimental and the calculated normal vibration modes. The assignment of fundamentals was established by the qualitative concurrence between the calculated and the observed band intensities and is assumed to be correct. The NBO results show that the most negative atomic charges are localized at $\mathrm{O} 12, \mathrm{O} 14$ and $\mathrm{N} 27$ of the qunoline ring and N16 of the piperazyinyl ring. HOMO - LUMO energy gap was reported to be $-4.086 \mathrm{eV}$. This value explains the possible charge transfer interaction with the molecule, which affects structure reactivity of the compound. The relatively high value of $\Delta \mathrm{E}_{\mathrm{HO} \mathrm{O}-}$ LUMO indicates that the title compound presents a high chemical stability and it has a low reactivity. Molecular Electrostatic Potential map shows that the negative potential sites are on oxygen, nitrogen and fluorine atoms and that the positive potential sites are around the hydrogen atoms. The theoretical UV-vis spectral analysis has also provided insight into the excitation energy and oscillator strength and predicted mainly the $\pi \rightarrow \pi^{*}$ type electronic transitions which are of intramolecular charge transfer type. The present quantum chemical study may lead to the understanding of the properties and activity of Sparfloxacin and may also help in extending its use for more medical applications.

\section{References}

1. Martin, S.J.; Meyer, J.M.; Chuck, S.K.; Jung, R.; Messick, C.R.; Pendland, S.L.; Levofloxacin and sparfloxacin: new quinolone antibiotics. Ann Pharmacother. 1998, 32(3), 320-36.

2. Jain, S., Jain, N.K.; Pitre, K.S. J. Electrochemical analysis of sparfloxacin in pharmaceutical formulation and biochemical screening of its Co(II) complex, Pharm. Biomed Anal., 2002, 29,795-801.

3. Marona, H.R.N.; Schapoval, E.E.S. Spectrophotometric determination of sparfloxacin in pharmaceutical formulations using bromothymol blue. J. Pharm. Biomed Anal. 2001,26, 501-504.

4. Faria, A.F.; de Souza, M.V.N.; de Almeida, M.V.; de Oliveira,M.A.L. Simultaneous separation of five fluoroquinolone antibiotics by capillary zone electrophoresis Anal. Chim. Acta 2006, 579, 185-192.

5. Lia,Y.L.; Haoa, X.L.; Jia, B.Q.; Xua, C.L.; Chena, W.; Shenb, C.Y.; Dingb, T. Rapid determination of 19 quinolone residues in spiked fish and pig muscle by highperformance liquid chromatography (HPLC) 
tandem mass spectrometry. Food Addit. Contam. 2009, 26, 306-313.

6. Jasmin, S.; Rasul Jan, M.; Inayatullah, Sultan, S. Sensitive spectrofluorimetric and spectrophotometric methods for determination of sparfloxacin in pharmaceuticals. J. Mex. Chem. Soc. 2012, 56(2), 109-114

7. Kłosińska-Szmurło, E.; Pluciński, F. A.; Grudzień, M.; Betlejewska-Kielak, K.; Biernacka, J.; Mazurek, A. P. Experimental and theoretical studies on the molecular properties of ciprofloxacin, norfloxacin, pefloxacin, sparfloxacin, and gatifloxacin in determining bioavailability. J. Biol. Phys. 2014, 40, 335-345.

8. Nadia El-Gamel, E.A.; Zayed, M.A. Synthesis, structural characterization and antimicrobial activity evaluation of metal complexes of sparfloxacin. Spectrochimica Acta A. 2011, 82, 414- 423.

9. Michael, E.; Guido ru“, S.; Fritz, SO*R.; Ulrike, H. Defluorinated Sparfloxacin as a New Photoproduct Identified by Liquid Chromatography Coupled with UV Detection and Tandem Mass Spectrometry. Antimicrob. Agents Chemother. 1998, 42, 1151-1159.

10. Ali K. Attia, * Mona M. Abdel-Moety and Samar G. Abdel-Hamid. Thermal analyses of some fluoroquinolone pharmaceutical compounds in comparison with molecular orbital calculations. New J. Chem., 2017, 41, 10189--10197

11. Somia, G.; Najma, S.; Muhammad, S. A.; Sana, S.; Mahwish A. New Method for Optimization and Simultaneous Determination of Sparfloxacin and Non Steroidal AntiInflammatory Drugs: Its In-Vitro Application. Am. J. Anal. Chem. 2012, 3, 328-337.

12. Fatma, A. M. A.; Gamal, A. S.; Hassan, F. A.; Ibrahim, H. R. Chemiluminescence Determination of Some Fluoroquinolones Using NBS-Luminol System. Asian J. Biom. \& Pharm. Sci. 2014, 4(29), 39-49.

13. Snehasis, J.; Mahendra, K. T.; Alice, B.; Dahryn, T.; Harish, S.; Khemraj, B. Fourier Transform Infrared and Ultraviolet-Visible Spectroscopic Characterization of Biofield Treated Salicylic Acid and Sparfloxacin. Nat. Prod. Chem. Res. 2015, 3-5.
14. Mamoun Abd El- kareem, S.M.; El desawy,M.; Hawash, M.A.; Fahmy, M.A. Structural investigation of sparfloxacin drug using mass spectrometry and MNDO semiempirical molecular orbital calculations. Int. J. Adv. Chem. 2018, 6(1), 74-78.

15. Fogarasi, G.; Pulay, P.; Durig, J.R. (Eds.), Vibtional Spectra and Structure, Elsevier, Amsterdam, 1985, 125.

16. Sundaraganesan, N.; Dominic, B. J. Vibrational spectra and fundamental structural assignments from HF and DFT calculations of methyl benzoate. Spectrochim. Acta, 2007, 68A, 771-777.

17. Pavia, D.L.; Lampman, G.M.; Kriz, G.S. Introduction to spectroscopy. (3rd edn), 2001, Thomson learning, Singapore.

18. Perdew, P.; Burke, K.; Wang, Y. Generalized gradient approximation for the exchangecorrelation hole of a many-electron system. Phys. Rev. B, Condensed Matter, 1996, 54,16533-16539.

19. Frisch, M.J. et al. Gaussian 09 manual (Gaussian, Inc., Wallingford CT, 2009)

20. Koopmans, T. Ordering of wave functions and eigenenergies to the individual electrons of an atom. Physica. 1933, 1, 104-113.

21. Ayers, P.W. Fukui Function in Chemical Reactivity Theory, A Density Functional View, P. K. Chattaraj Ed, New York, USA CRC Press, Taylor\&Francis Group, 2009, 255-265.

22. Parr, R.G.; Pearson, R.G. Absolute hardness: companion parameter to absolute electronegativity. J. Am. Chem. Soc., 1983,105, 7512-7516.

23. Mulliken, R.S. A new electron affinity scale; together with data on valence states and on valence ionization potentials and electron affinities. J. Chem. Phys., 1934, 2, 782-793.

24. Pearson, R.G. Hard and soft acids and bases. J. Am. Chem. Soc., 1963, 85, 3533-3539.

25. Vektariene,A.; G. Vektaris, G.; J. Svoboda, J. A theoretical approach to the nucleophilic behavior of benzofused thieno [3, 2-b] furans using DFT and HF based reactivity descriptors. J. Org. Chem., 2009, vii,311329. 
26. Pearson, R.G. Absolute electronegativity and hardness correlated with molecular orbital theory. Procee. Nat. Acad. Sci. 1986, 83, 8440-8441.

27. Chattaraj, P.K.; Roy, D.R. Update 1 of: Electrophilicity index. Chem. Rev., 2007, 107, PR46-PR74.

28. Rubarani, P. G.; Sampath K. S. Natural Bond Orbital (NBO) Population Analysis of 1Azanapthalene-8-ol. Acta Physica Polonica A. 2014, 125, 18-22.

29. Arjunan, V.; Devi, L.; Subbalakshmi,R.; Rani,T.; Mohan,S. Synthesis, vibrational, NMR, quantum chemical and structureactivity relation studies of 2-hydroxy-4methoxyacetophenone Spectrochim. Acta A . 2014, 130, 164-177.

30. El-Gammal, O.A.; Rakha, T.H.; Metwally,H.M.; Abu El-Reash, G.M. Synthesis, characterization, DFT and biological studies of isatinpicolinohydrazone and its $\mathrm{Zn}$ (II), Cd (II) and $\mathrm{Hg}$ (II) complexes. Spectrochim. Acta A. 2014,127, 144-156.
31. Koopsmans, T.A. About the assignment of wave functions and eigenvalues to the individual electrons of an atom. Physica 1934, 1, 104-113.

32. Parr,R.J.; Szentpaly,L.V.; Liu,S. Electrophilicity Index. J. Am. Chem. Soc. 1999, 121, 1922-1924.

33. Luque, F.J.; Lopez, J.M.; Orozco,M. Perspective on "Electrostatic interactions of a solute with a continuum. A direct utilization of $a b$ initio molecular potentials for the prevision of solvent effects Theor. Chem. Acc. 2000, 103, 343-345

34. Kobinyi,H.; Folkers, G.; Martin,Y.C. 3D QSAR in Drug Design, Recent Advances Kluwer Academic Publishers. 1998 , vol. 3,

35. Moro,S.; Bacilieri, M.; Ferrari,C.; Spalutto,G. Curr. Autocorrelation of molecular electrostatic potential surface properties combined with partial least squares analysis as alternative attractive tool to generate ligandbased 3D-QSARs. Curr Drug Discov Technol. 2005, 2(1), 13-21. Moro S1, Bacilieri M, Ferrari C, Spalluto G. 